\title{
KEDUDUKAN FIQH DI INDONESIA \\ PASCA KEMERDEKAAN
}

\section{Zulhamdi* $^{*}$}

\begin{abstract}
ABSTRAK
Islam yang masuk di Indonesia lebih dipahami sebagai proses Arabisasi atau lebih berkiblat kepada Arab dengan menafikan nilainilai lokalitas, kemudian labirnya kebijakan pemerintah colonial dengan teori resepsinya, yaitu yang menjadi patokan dalam penyelenggaraan bukum di Indonesia adalah bukum adat, sedangkan bukum Islam baru bisa dijadikan sebagai rujukan setelah terlebih dabulu diresepsi oleb bukum adat. Adapun tujuan dalam penulisan jurnal ini adalah Untuk Mengetahui tokoh-tokoh fiqib terkenal serta buku dan pemikiran fiqh di Indonesia pada masa kemerdekaan, Untuk. Mengetahui isi buku penting dalam perkembangan fiqh masa, Untuk Mengetabui Kedudukan figh dalam sistem bukum Indonesia dan bubungan fiqh dengan perundang-undangan Indonesia, dan Metode penulisan merupakan studi penelitian dengan cara menelaah sejumlab buku-buku, membuka web-web untuk memperoleb data, teori dan konsep yang berhubungan dengan pembahasan ini. Dengan menggunakan metode dan teknik pengumpulan data tersebut, kiranya dapat terkumpul selurub data yang dibutubkan untuk mendukung penulisan jurnal ini, dapat pula menemukan suatu kesimpulan yang objektif. Di antara hasil ijtihad Hasbi yang mencerminkan pemikiran Fiqh Indonesia terlihat dalam fatwa bukum jabat tangan antara lakilaki dan perempuan. Di sini ia berbeda pendapat dengan fatwa Majelis Tarjih Mubammadiyah dan Abmad Hassan dari Persis yang mengharamkan praktik dan perilaku ini. Usaba untuk. merekonstruksi format fiqh baru, menurut pandangan Hazairin, dapat dimulai dengan tafsir otentik atas al-Qur'an. Dalam analisis dan hasil temuan dari studi tentang pemikiran waris Hazairin yang dilakukan oleh Al-Yasa Abu Bakar, dapat ditarik kesimpulan bahwa karakter sumber-sumber hukum Islam, yakni sunnah, ijma', dan qiyas memungkinkan untuk digugat hasil ketetapan ijtihadnya.
\end{abstract}

\section{Kata Kunci: Kedudukan, Fiqh dan Pasca Kemerdekaan}

* Penulis adalah Dosen Hukum Islam IAIN Malikussaleh Lhokseumawe, Email: zoel_hamdi@yahoo.co.id 


\section{PENDAHULUAN}

Di masa kolonial Belanda dan Jepang, hukum Islam di Nusantara ini diselimuti keterbelakangan dalam berpikir, ia lebih tersudut pada aspek ibadah, bercorak satu mazhab, memperkeras taklid, larangan talfik dan larangan membuka pintu ijtihad. Kenyataan ini masih dipersuram dengan miskinnya kajian metodologis. Pemikiran hukum Islam lebih mementingkan hasil daripada proses penyimpulan hukum, mengabaikan maslahat sebagai salah satu tujuan hukum Islam, karena pendapat ulama seringkali di impor begitu saja sebagai sebuah kebenaran tanpa dikaji ulang. Islam yang masuk di Indonesia pada waktu itu lebih dipahami sebagai proses Arabisasi atau lebih berkiblat kepada Arab dengan menafikan nilai-nilai lokalitas.

Lebih parah lagi kondisi ini diperkeruh dengan lahirnya kebijakan pemerintah colonial dengan teori resepsinya, yaitu yang menjadi patokan dalam penyelenggaraan hukum di Indonesia adalah hukum adat, sedangkan hukum Islam baru bisa dijadikan sebagai rujukan setelah terlebih dahulu diresepsi oleh hukum adap. Kondisi inilah kiranya yang menggugah kesadaran para intelektual muslim untuk melakukan perubahan, agar muslim Indonesia tidak terjebak pada perdebatanperdebatan yang tidak menyentuh permasalahan substantif. Hasbi Ash Shiddieqy merupakan salah satu tokoh yang ikut mendukung gerakan kembali kepada Al-Qur'an dan Sunnah sebagai bentuk perlawanan terhadap pengekangan hukum Islam yang didominasi hukum adat. Selanjutnya, dianggap perlu untuk menggagas sebuah fiqh yang berorientasi lokal yang lebih dikenal dengan istilah fiqh keindonesiaan. Hal ini didasari pada, bahwa selama ini pemahaman umat Islam Indonesia terhadap hukum Islam masih sangat kearab-araban, sehingga perlu kiranya membangun kesadaran untuk menggagas fiqh lokalitas yang dapat mengakomodasi kepentingan sosial muslim Indonesia.( H. Kusdar tt)

Hal inilah yang menarik untuk ditelaah lebih lanjut dengan melihat fakta sejarah, bagaimana lahirnya fiqh keindonesiaan yang diyakini akan mendominasi proses pembaharuan hukum Islam di masa yang akan datang. Yang menjadi tujuan dalam penulisan ini adalah Untuk Mengetahui tokoh-tokoh fiqih terkenal serta buku dan pemikiran fiqh di Indonesia pada masa kemerdekaan, Untuk Mengetahui isi buku penting dalam perkembangan fiqh masa, Untuk Mengetahui Kedudukan fiqh dalam sistem hukum Indonesia dan hubungan fiqh dengan perundangundangan Indonesia, dengan menggunakan Metode penulisan berupa studi penelitian dengan cara menelaah sejumlah buku-buku, membuka web-web untuk memperoleh data, teori dan konsep yang berhubungan 
dengan pembahasan ini. Dengan menggunakan metode dan teknik pengumpulan data tersebut, kiranya dapat terkumpul seluruh data yang dibutuhkan untuk mendukung penulisan jurnal ini, dapat pula menemukan suatu kesimpulan yang objektif.

\section{HASIL DAN PEMBAHASAN}

\section{A. Tokoh-tokoh Fiqh Terkenal, Karya dan Pemikiran Fiqh di Indonesia Pasca Kemerdekaan}

\section{Pemikiran Hukum Hasbi ash-Shiddiqi}

Pada sekitar tahun 1940-an. Dengan artikel pertamanya yang berjudul "Memoedabkan Pengertian Islam", Hasbi menyatakan pentingnya pengambilan ketetapan fiqh dari hasil ijtihad yang lebih cocok dengan kebutuhan nusa dan bangsa Indonesia, agar fiqh tidak menjadi barang asing dan diperlakukan sebagai barang antik. Hasbi terlihat gamang akan prospek dan masa depan hukum Islam di Indonesia yang tidak mempunyai arah yang jelas. Menurutnya, pengkultusan (taqdis) atas pemikiran hukum Islam yang telah terjadi dan yang hingga sekarang masih berlangsung, harus ditinjau ulang dalam kerangka dasar meletakkan sendi ijtihad baru. Konsep dan pemikiran hukum Islam yang terasa tidak relevan dan asing harus segera dicarikan alternatif baru yang lebih memungkinkan untuk dipraktikkan di Indonesia.

Hingga interval waktu yang cukup lama, tepatnya hingga tahun 1948, gagasan awal Fiqh Indonesia ini belum atau bahkan tidak mendapatkan respons yang memadai (positif) dari masyarakat. Melalui tulisannya yang ber-judul "Menghidupkan Hukum Islam dalam Masyarakat" yang dimuat dalam majalah Aliran Islam, Hasbi coba mengangkat kembali ide besarnya ini. Dalam tulisan itu dikatakan bahwa eksistensi hukum Islam pada tataran praktis telah sampai pada tingkat dekadensi yang klinis, tampil bagai sosok yang terasing, tidak berarti dan juga tidak berdaya guna. (Nourouzzaman Siddiqi, tt :215-216) Kehadirannya tidak lagi dianggap ada oleh umat, karena tidak sanggup lagi mengakomodir berbagai tuntutan perubahan zaman.

Nalar berpikir yang digunakan Hasbi dengan gagasan Fiqh Indonesia adalah satu keyakinan bahwa prinsip-prinsip hukum Islam sebenarnya memberikan ruang gerak yang lebar bagi pengembangan dan ijtihad-ijtihad baru. Dasar-dasar hukum Islam yang selama ini telah mapan dan mantap, seperti ijma', qiyas, mashlahah mursalah, 'urf dan prinsip "perubahaan hukum karena perubahan masa dan tempat", justru akan menuai ketidaksesuaian ketika tidak ada lagi ijtihad baru. Dengan berpegang pada paradigma itu, dalam konteks pembangunan semesta 
sekarang ini, gerakan penutupan pintu ijtihad (insidad bab al- ijtihad) merupakan isu usang yang harus segera ditinggalkan. (Hasbi ashShiddieqy, 1966: 42)

Puncak pemikiran ini terjadi pada 1961, ketika dalam satu acara Dies Natalis IAIN Sunan Kalijaga yang pertama, ia memberikan makna dan definisi Fiqh Indonesia secara cukup artikulatif. Dalam orasi ilmiahnya yang bertema "Syari'at Islam Menjawab Tantangan Zaman", Hasbi secara tegas mengatakan:

"Maksud untuk mempelajari syariat Islam di universitas-universitas Islam sekarang ini supaya fiqh atau syariat Islam dapat menampung selurub kemaslahatan masyarakat dan dapat menjadi pendiri utama bagi perkembangan bukum-bukum di tanah air kita yang tercinta ini. Maksud kita supaya dapat menyusun suatu fiqh yang berkepribadian kita sendiri sebagaimana sarjana-sarjana Mesir sekarang ini sedang berusaha me-Mesirkan fiqhnya.

Fiqh Indonesia ialah fiqh yang ditetapkan sesuai dengan kepribadian Indonesia, sesuai dengan tabi'at dan watak. Indonesia.

Fiqh yang berkembang dalam masyarakat kita sekarang ini sebagiannya adalah figh Hijaz, fiqh yang terbentuk atas dasar adat istiadat dan 'urf yang berlaku di Hijaz, atau figh Mesir, yaitu figh yang telah terbentuk atas dasar adat istiadat dan kebiasaan Mesir, atau fiqh Hindi, yaitu fiqh yang terbentuk atas "urf dan adat istiadat yang berlaku di India.

Selama ini, kita belum menunjukean kemampuan untuk berijtibad, menujukkan bukum fiqh yang sesuai dengan kepribadian Indonesia. Karena itu kadang-kadang kita paksakan figh Hijazi atau fiqh Misri atau fiqh Iraqi berlaku di Indonesia atas dasar taklid. (Hasbi ash-Shiddieqy, 1966: 43)

Hasbi mengamati bahwa hingga tahun 1961, ulama di negeri ini belum mampu melahirkan fiqh yang berkepribadian lndonesia. Menurutnya, salah satu faktor yang menjadi penghambat adalah adanya ikatan emosional yang begitu kuat (fanatik, ta'ashub) terhadap madzhab yang dianut umat Islam. Menyadari ketidakmungkinan akan munculnya pemikiran progresif dari kalangan ulama konservatif, maka Hasbi mengajak kalangan Perguruan Tinggi Islam di Indonesia untuk mencetak kader-kader mujtahid dengan karakter khas yang dapat meneruskan proyek Fiqh Indonesia. Menurut Hasbi, persoalan ini cukup mendesak, sebab apabila pengembangan proyek fiqh Indonesia tidak berangkat dari kalangan Perguruan Tinggi, maka harapan untuk memperkenalkan hukum Islam secara kohesif kepada masyarakat akan gagal. Sebagai konsekuensi lebih lanjut, hukum Islam barangkali hanya akan dikenal dalam dimensi 
ibadah saja, dan itu pun tidak lengkap. Sementara dimensi-dimensi lainnya akan hilang, tenggelam ditelan masa.

Untuk membentuk fiqh baru ala Indonesia, diperlukan kesadaran dan kearifan yang tinggi dari banyak pihak, terutama ketika harus melewati langkah pertama, yaitu melakukan refleksi historis atas pemikiran hukum Islam pada masa awal perkembangannya. Perspektif ini mengajarkan bahwa hukum Islam baru bisa berjalan dengan baik apabila sesuai dengan kesadaran hukum masyarakat. Yakni, hukum yang dibentuk oleh keadaan lingkungan, atau dengan kebudayaan dan tradisi setempat, bukan dengan memaksakan format hukum Islam yang terbangun dari satu konteks tertentu kepada konteks ruang dan waktu baru, yang jauh berbeda (Dalam sejarahnya pemikiran hukum Islam telah menampakkan berbagai karakteristik yang semuanya menggambarkan karakter kebudayaan yang melatarbelakanginya karakter fiqh di Hijaz menampakkan ciri tradisional sebagaimana masyarakatnya yang bercirikan tertutup mapan, tidak banyak gejolak perubahan. Sedangkan di Irak harus bercirikan rasional, karena karakter budaya kosmopolitan masyarakat Irak yang juga rasional. Gambaran karakteristik pemikiran hukum Islam ini semakin jelas dengan adanya qaul qadim dan qaul jadid dari asSyafi'i, simbol mana menggambarkan pengaruh budaya Irak dan Mesir dalam fatwa hukum agama. Hebatnya fatwa yang kemudian ini tidak dihadirkan sebagai sarana revisi atas fatwa yang terdahulu, walaupun adakalanya dalam satu konteks masalah yang sama, diktum hukum baru itu sama sekali berbeda). Aneksasi demikian tentu akan sia-sia, bukan karena kurang komplitnya pemikiran lama, melainkan lebih karena sifatnya yang sudah anakronistik.

Mempertimbangkan kehadiran tradisi (adat urf) setempat sebagai acuan pembentukan sebuah format pemikiran hukum Islam baru, dalam amatan Hasbi, menjadi satu keniscayaan. (Hasbi ash-Shiddieqy, 1966: 35) Syari'at Islam menganut asas persamaan. Egalitarianisme Islam memandang semua masyatakat adalah sama di hadapan Allah. Konsekuensinya, semua 'urf dari setiap masyarakat tidak hanya urf dari masyarakat Arab saja, dapat menjadi sumber hukum. Sejalan dengan itu, Islam datang tidak dimaksudkan untuk menghapus kebudayaan dan juga syari'at agama yang telah ada, selama ia tidak bertentangan dengan prinsip ajaran Islam, yaitu tauhid. Dengan demikian, semua 'urf dalam batas-batas tertentu akan selalu dapat diterima sebagai sumber hukum Islam. Dari titik ini, pembentukan Fiqh Indonesia harus mempertimbangkan 'urf yang berkembang di Indonesia.

Dari uraian di atas dapat ditarik pemahaman bahwa ide Fiqh Indonesia atau "fiqh yang berkepribadian Indonesia", yang telah dirintis oleh Hasbi mulai tahun 1940, berlandaskan pada konsep bahwa hukum Islam 
(fiqh) yang diberlakukan untuk umat Islam Indonesia adalah hukum yang sesuai dan memenuhi kebutuhan mereka, yaitu hukum adat yang telah berkembang dalam masyarakat Indonesia, yang tidak bertentangan dengan syara'. Usaha ini harus didukung secara penuh dengan proses internalisasi dan inkorporisasi fatwa-fatwa hukum ulama dahulu yang relevan untuk konteks sosial dan budaya Indonesia, dan menjadikannya sebagai bagian yang tak terpisahkan dari konsep fiqh baru yang digagas. Dengan demikian, tidak akan terjadi clash antara fiqh dengan adat, dari sikap mendua masyarakat dalam hal menentukan kompetensi materi hukum yang dipilih, adat atau figh, dapat dihindari.

Dalam pandangan Hasbi, pemikiran hukum Islam harus berpijak pada prinsip mashlabah mursalah, keadilan, dan kemanfaatan, serta sadd adzdzariah. Kesemua prinsip itu yang merupakan prinsip gabungan dan dipegang oleh para imam madzhab, khususnya aliran Madinah dan Kufah, telah terbukti mampu membawa ketertiban dan kesejahteraan dalam masyarakat. (Nouruzzaman Siddiqi, tt: 65) Prinsip mashlahah mursalah mengandaikan bahwa eksistensi sebuah hukum, pada dasarnva dimaksudkan untuk melahirkan kemaslahatan bagi manusia, baik dalam level dharurat, hajiyat, maupun tabshiniyyat. (Hasbi ash-Shiddieqy, 1975: 186187) Prinsip kemaslahatan dari ketiga level tersebut (dharurat, hajiyat, dan tahsiniyat) harus mencakup al-kulliyah al-khams, yaitu terpeliharanya jiwa, agama, akal, keturunan dan harta Tahap demi tahap pencapaian kemaslahatan ini dijaga eksistensinya oleh dan sekaligus menjadi tujuan disyari'atkannya Islam (maqashid asy-syari’ab), Prinsip ini sejalan dengan siyasah syar'iyyah dalam hal bahwa ia dimaksudkan sebagai kebijakan untuk membuat masyarakat lebih dekat pada kebaikan dan jauh dari segala keburukan dan kerusakan. (Hasbi ash-Shiddieqy, 1966:11 -12)

Dalam buku Falsafah Hukum Islam, Hasbi menandaskan bahwa berhujjah dengan mashlabah mursalah merupakan satu keharusan. Prinsip ini sesuai dengan keumuman syari'at, yang berarti menjadi landasan yang paling mungkin bagi perputaran dan berubahnya ketentuan hukum, sesuai konteks yang mengitarinya. Menafikan prinsip mashlahah mursalah berarti membekukan syariat. Hal itu karena berbagai persoalan yang terus muncul dan berkembang tidak begitu saja mudah dan dapat diselesaikan dengan mendasarkan pada dalil tertentu. (Hasbi ash-Shiddieqy, 1975: 3637) Oleh karena itu, prinsip ini diharapkan akan mampu memecahkan problem metodologi penetapan hukum, khususnya qiyas, yang aplikasinya terlalu rigid dan kaku, terjebak dalam kungkungan teks.

Dalam pandangan Hasbi, keberadaan prinsip mashlabah mursalah dalam teori hukum Islam akan memberikan ruang yang lebih terbuka bagi implementasi segala model baik lama maupun baru- istinbath hukum, 
dalam arti bahwa metode istinbath hukum yang dipakai tidak lagi monolitik (model kaca mata kuda), seperti yang selama ini berjalan, yakni melalui metode qiyas. Jika dibandingkan dengan qiyas yang semata dikaitkan dengan teks, maka mashlahah mursalab jelas lebih komprehensif, sebab ia dihubungkan dengan jiwa syari'at. Masblabah mursalab dalam pandangan Hasbi merupakan rahasia tasyrì" (agama), di mana efek kemaslahatan dan antisipasi kerusakan menjadi teleogi.

Dari uraian di atas, tampak bagaimana sebuah prinsip yang dipegang oleh Hasbi mampu memberikan implikasi jauh bagi pilihan pendekatan dan metode istinbath hukum, terutama pada konteks pembahasan fiqh Indonesia. Dalam hal ini Hasbi cukup bebas dan terbuka dalam menentukan metode yang layak pakai untuk mengembangkan pemikirannya itu. Dengan mengingatkan pentingnya pendekatan sejarah yang kritis misalnya, ia menawarkan metode analogi-deduktif, satu model istinbath hukum yang pernah dipakai oleh imam Abu Hanifah untuk membahas satu permasalahan yang tidak ditemukan ketentuan hukumnya dalam khazanah pemikiran terdahulu (klasik).

Mempertimbangkan keberadaan sosio-kultural di dalam upaya merumuskan satu ketetapan hukum Islam yang sesuai dengan kepribadian Indonesia, berarti menakar keberadaan 'urf yang ada. Pandangan ini bukan saja wajar melainkan niscaya, mengingat dalam catatan sejarah, pengambilan urf sebagai bagian dari sumber hukum Islam telah sering dilakukan. Upaya yang harus ditempuh adalah melakukan pemilahan terhadap urf yang ada, membandingkan serta men-tarjih-nya dengan dasar hukum yang lebih otoritatif, yakni Al-Quran dan hadits. Langkah ini penting untuk dilakukan bagi kemungkinan lahirnya fiqh baru yang berlaku untuk muslim Indonesia.

Sejauh yang dapat dilacak, dan berdasarkan pertimbangan metode dan pendekatan hukum yang menjiwai tema pemikiran Fiqh Indonesia, beberapa aplikasi pemikiran Hasbi secara gradual juga telah menambahkan makna dan orientasi dari tema pemikiran ini. Beberapa hasil ijtihad yang pernah dilakukan Hasbi, yang meliputi hampir seluruh aspek permasalahan fiqh (Dalam bidang ibadah ijtihad hukum Hasbi meliputi permasalahan-permasalahan niat shalat (ushalli) dan puasa, talqin, kenduri kematian, syafa'at, keramat, MTQ, shalat Jum'at, dan perbedaan matla'. Dalam bidang mu amalah, di antaranya adalah tentang perdagangan transfusi darah dan jabat tangan. Dalam bidang munakahat, ijtihadnya dapat dilihat pada pemikirannya tentang Rancangan Undang-undang Pokok Perkawinan dan status hukum poligami Sedangkan dalam bidang qada', di antara ijtihad yang telah dilakukan Hasbi adalah tentang status hukum pidana mati. Di samping itu, Hasbi juga aktif memberikan fatwa 
agama yang secara rutin muncul di rubrik SoaI Jawab Hukum dalam majalah As-Syir'ah. (Hasbi ash-Shiddieqy, 1975: 171-21) baik ibadah, mu'amalah, munakahat, maupun qadha', mengekspresikan pemikiran fiqh dengan cita rasa budaya Indonesia.

Di antara hasil ijtihad Hasbi yang mencerminkan pemikiran Fiqh Indonesia terlihat dalam fatwa hukum jabat tangan antara laki-laki dan perempuan. Di sini ia berbeda pendapat dengan fatwa Majelis Tarjih Muhammadiyah dan Ahmad Hassan dari Persis (Mengenai hukum kebolehan berjabat tangan mushafahahri anlara laki-lakl dan perempuan ini. Hasbi bahkan harus berpolemik dengan A. Hasan. Dalam hal ini A. Hasan meminta agar kasus ini diangkat ke forum perdebatan resmi (terbuka) dengan menunjuk K H. Ali Maksum dari Pesantren Krapyak sebagai wasitnya. Mengenai perdebatan keduanya dapat dilihat pada (Akh Minhaji, 2001: 246-250) yang mengharamkan praktik dan perilaku ini. Hasbi menolak mengharamkan praktik jabat tangan antara laki-laki dan perempuan karena beberapa alasan, di antaranya adalah karena hukum haram tersebut dilandaskan pada qiyas.

Dalam pandangan Hasbi, mengharamkan sesuatu harus berdasarkan dalil nash yang qath'i, tidak boleh hanya dengan qiyas. Oleh karena tidak ada dalil yang qath'i, baik dalam al-Qur'an maupun AsSunnah, yang mengharamkan praktik jabat tangan antara laki-laki dan perempuan maka praktik seperti itu tidak dilarang agama. (Hasbi ashShiddieqy, 1975: 173-178)

Terlepas dari tidak adanya dalil yang menunjukkan keharaman jabat tangan antara laki-laki dan perempuan dan juga bantahan rasional yang diberikan, tampaknya Hasbi menyadari hahwa praktik seperti itu sudah sekian lama hidup dan menjadi tradisi (urf) di masyarakat Indonesia. Karena Hasbi tidak melihat tradisi jabat tangan antara laki-laki dan perempuan sebagai hal yang berhahaya maka tidak ada alasan untuk melarangnya.

Ijtihad Hasbi lainnya yang bisa diangkat di sini adalah tentang zakat. Dengan mengacu pada pandangan Abu Hanifah yang berbeda dengan pandangan Jumhur Ulama, Hasbi berpendapat mesin-mesin produksi di pabrik besar wajib dizakati. (Hasbi ash-Shiddieqy, 1975: 204) Pandangan ini cukup relevan dengan konteks pembangunanisme negara yang membutuhkan banyak modal.

Dengan demikian, ia bisa digunakan untuk membiayai atau sebagai dana penunjang pembangunan di sektor yang lain. Sementara konsentrasi pelaksanaan dan pembagian zakat yang hanya berputar-putar di sekitar orang-orang yang secara ekonomi lemah sudah saatnya dipikirkan kembali relevansinya. 
Dalam pandangan Hasbi, wewenang untuk mengurus zakat ada pada pemerintah, dan hal itu adalah satu paket dengan proyek penyelenggaraan kepentingan dan kesejahteraan rakyat, baik muslim maupun non muslim. Oleh karena itu, pungutan zakat seharusnya juga tidak hanya ditujukan kepada kaum muslim, akan tetapi juga kepada masyarakat non muslim. Dengan mengacu pada argumen bahwa hukum zakat berlaku dalam setiap agama, dan bahwa sahabat Umar pernah memungut zakat atas Nasrani golongan Tagluba, dalam hal ini, tampaknya Hasbi tidak menarik garis demarkasi yang tegas antara zakat dan pajak. Asumsi ini menjadi semakin valid dengan melihat pandangannya yang lain tentang perlunya pemerintah membentuk lembaga khusus, semacam dewan zakat (bait al-mal) yang berdiri sendiri, terlepas dari departemen keuangan atau instansi keuangan lainnya. (Hasbi ash-Shiddieqy, 1975: 208) dan lihat lebih lanjut (Hasbi ash-Shiddieqy, 1976: 22-43) (Dalam hal ini, Hasbi terlihat ingin memisahkan pengelolaan kekayaan hasil pungutan zakat dari kekayaan negara yang diperoleh dari pajak. Jika demikian halnya maka persoalan yang belum dipecahkan Hasbi adalah tentang pungutan ganda zakat dan pajak, satu jenis pungutan dengan objek dan tujuan yang sama.

Persoalan lain yang sebenarnya masih terkait dengan masalah zakat adalah tentang orang yang berhak menerima zakat. Pandangan Hasbi yang cukup berani dalam konteks ini adalah bahwa orang miskin non muslim yang tidak sanggup bekerja dimasukkan sebagai golongan fakir miskin yang berhak menerima zakat. (Hasbi ash-Shiddieqy, 1976: 47) Walaupun berbeda dengan mainstream konsep fiqh ulama klasik, namun alasan yang diajukannya cukup mewakili pandangan dunianya, yakni dalam rangka membina kesejahteraan bersama antar umat manusia dalam satu negara. Dari sini terlihat keistimewaan (maziyah) hukum Islam dan nilai universalnya secara implisit coba ditunjukan oleh Hasbi, bahwa hukum ini sejalan dengan konstitusi dan hukum positif negara, dan bisa digunakan sebagai sarana bagi proses pembangunan.

\section{Pemikiran Hukum Hazairin}

Masalah besar yang dihadapi umat Islam di Indonesia adalah bagaimana membentuk satu pemikiran hukum Islam yang sesuai dengan tradisi (adat) yang ada di wilayah ini. Pandangan seperti ini merupakan proses awal dari keseluruhan cita-cita untuk menjadikan hukum Islam sebagai bagian integral dari sistem hukum Nasional. Kenyataan bahwa selama ini umat Islam hanya mengikuti jalur pemikiran fiqh madzhab Syafi'i ternyata memberikan pengaruh terhadap karakter pembaruan dan nasib pemikiran hukum Islam di Indonesia. 
Dibandingkan dengan negara-negara lain yang tidak pernah dijajah oleh Belanda, Indonesia termasuk negara yang kurang beruntung. Hal ini dapat dimengerti dengan tidak adanya perhatian pemerintah koloni secara cukup proporsional dalam proses pembenahan dan pengembangan hukum Islam, terutama dalam konteks legislasi hukum Islam yang dicitakan dapat dipakai sebagai acuan perundang-undangan di lingkungan Peradilan Agama. Oleh karena itu, wajar kiranya jika hingga 1960- an, kitab-kitab hukum fiqh yang dibuat oleh para mujtahid pada abad pertengahan, masih menjadi acuan utama dalam proses pengambilan keputusan di lingkungan Peradilan Agama.

Fenomena ini sangat memprihatinkan sebab karakter pemikiran dalam kitab fiqh klasik itu secara umum sudah tidak mampu lagi memenuhi kebutuhan umat Islam di Indonesia. Pergumulan para mujtahid dengan konteks sosial politik Timur Tengah, sangat mempengaruhi hasil ijtihad yang mereka lakukan sehingga tidak cocok kalau dipaksa untuk dilaksanakan di Indonesia. Dengan demikian, permasalahan-permasalahan fiqh, terutama dalam bidang mu'amalah, membutuhkan rumusan baru agar lebih relevan dengan situasi dan kondisi serta adat dan budaya Indonesia.

Setting sejarah sosial pemikiran hukum Islam di atas telah mendorong Hazairin, Mengenai biografi Hazairin dapat dilihat pada (Hasan Shadily (ed.), 1980) dan (Sayuti Thalib, tt.) untuk membentuk Fiqh Madzhab Nasional Indonesia. Dalam konteks pembicaraan bahwa permasalahan yang dihadapi umat Islam Indonesia adalah masalah hukum, dan bahwa karakteristik hukum Islam berbeda dengan unsur keimanan dan keislaman lainnya, maka menurut Hazairin, eksistensi hukum Islam bisa dikatakan sedang mencari-cari tempat di dalam masyarakat. Dari titik berangkat ini, ide Fiqh Madzhab Nasional Indonesia menuai signifikansinya. Dalam amatan Hazairin, bentangan perjalanan sejarah hukum Islam yang mewartakan bahwa pintu ijtihad senantiasa terbuka bagi para mujtahid, cukup bisa dijadikan alasan dan pertimbangan akan perlunya memikirkan konstruk madzhab baru yang lebih sesuai dengan masyarakat Indonesia. Menurutnya, madzhab hukum Syafi'i harus dikembangkan sehingga mampu menjadi penghubung bagi resolusi problem-problem spesifik masyarakat Indonesia.

Berbeda dengan pandangan Hasbi ash-Shiddieqy yang menginginkan membentuk Fiqh Indonesia dengan cara menggunakan semua madzhab hukum yang telah ada (muqaranah al-madzabib) sebagai bahan dasar dan sumber materi utamanya, Hazairin justru menginginkan pembentukan fiqh madzhab nasionalnya ini dengan titik berangkat hanya dari pengembangan fiqh madzhab Syafi'i. (Syamsul Wahidin dan Abdurrahman, 1984: 87-88), (K.N. Sofyan Hasan dan Warkum Sumitro, 
1994 :102-103.) Pandangan Hazairin ini lebih didasarkan pada kenyataan bahwa madzhab Syafi'i telah sekian lama dianut oleh masyarakat Indonesia, sehingga karakternya bisa dikatakan paralel dengan nilai-nilai adat Indonesia. Bagi Hazairin, eksistensi hukum adat tidak bisa dikesampingkan begitu saja di dalam proses pembuatan hukum Islam di Indonesia.

Penilaian yang kurang tepat terhadap hukum adat, terutama ketika ia dianggap sebagai faktor yang menghalangi pengembangan hukum Islam, dan begitu juga sebaliknya, tidak bisa lepas dari kondisi politik kolonial masa lalu, terutama sejak munculnya teori receptie. Menurut Hazairin, umat Islam tidak perlu lagi terjebak dalam kontroversi tentang status hukum Islam hanya karena adanya propaganda dari teori iblis ini. Mengenai pandangan Hazairin yang menganggap teori receptie sebagai teori iblis dapat dilihat pada (Hazairin, 1976: 7-8). Dia menyarankan agar umat Islam memakai hukum Islam sebagai hukum yang ditaati guna menata kehidupan sehari-hari. Selanjutnya, peradilan Islam dimungkinkan untuk berdiri dan integral dengan peradilan negara, yang dalam hal ini berada di bawah pengawasan Mahkamah Agung.

Menurut Hazairin, dengan merujuk pada pasal 29 ayat 1 UUD 1945, maka sebenarnya tidak perlu lagi terjadi pertentangan antara sistem hukum adat, hukum positif, dan hukum agama. Begitu juga tidak boleh lagi ada satu ketentuan dan hukum baru yang bertentangan dengan kaidahkaidah hukum Islam dan juga hukum agama yang lain, dan begitu pula sebaliknya. Negara wajib mengayomi setiap orang untuk bisa menjalankan ajaran-ajaran agama yang diyakininya. Selain itu, negara juga wajib mengatur dan mengontrol sistem hukum Islam, terutama aspek mu'amalahnya, yang memang membutuhkan bantuan negara dalam implementasinya. (Hazairin, 1973: 18-20)

Dengan melihat paparan di atas, ide Hazairin tentang Fiqh Madzhab Nasional Indonesia boleh dikatakan merupakan prolifelari (pengembangan) dari gagasan Fiqh Madzhab Indonesia yang digagas oleh Hasbi ash-Shiddieqy. Titik temu pandangan keduanya terletak pada entri bahwa hukum adat masyarakat Islam Indonesia harus digunakan sebagai bahan pertimbangan utama dalam proses pembentukan hukum Islam di Indonesia. Dalam hal ini, Hazairin berusaha melempangkan pemikiran Hasbi yang sebelumnya kurang diperhatikan (unresponsive), yaitu upaya mempersatupadukan nilai-nilai yang berasal dari adat maupun hukum Islam ke dalam satu entitas hukum. Dengan upaya penyelarasan ini, setidaknya akan menghasilkan satu hasil ijtihad baru yang lebih mendekatkan hukum Islam kepada masyarakat muslim Indonesia, sehingga penyimpangan (biyal), seperti yang ditempuh oleh beberapa 
negara Islam (dalam upaya mereformasi undang-undang hukum keluarga), tidak perlu dilakukan. (Hazairin, 1976,: 3-18).

Kesejajaran pemikiran Hazairin dengan pemikiran Hasbi ashShiddieqy juga dapat dilihat pada perubahan nama dari tema pemikiran yang ia usulkan. Pada buku yang berjudul Hukum: Kekeluargaan Nasional, Hazairin melakukan perubahan dari istilah "Madz̧ab Nasional" ke "Madrhab Indonesia", suatu konsep yang jelas mengantisipasi ide Fiqh Indonesia sebagaimana yang pernah ditawarkan oleh Hasbi ash-Shiddieqy. (Hazairin, 1982: 5-6). sebagaimana yang dikutip oleh (Retno Lukito, 1988: 76).

Dalam amatan Hazairin, fiqh abl as-sunnah terbentuk dalam masyarakat Arab yang bersendikan sistem kekeluargaan patrilineal, dalam suatu masa sejarah, ketika ilmu pengetahuan tentang bentuk-bentuk kemasyarakatan belum berkembang. Hal ini menyebabkan para mujtahid berpandangan sempit, karena belum adanya perbandingan-perbandingan mengenai berbagai hal terkait masalah hukum, terutama dalam masalah kewarisan. Oleh karena itu, sangat wajar apabila dalam pengimplementasiannya terjadi konflik antara sistem kewarisan yang dihasilkan abl as-sunnah dengan sistem kewarisan adat dalam berbagai lingkungan masyarakat Indonesia.

Dengan cara pandang seperti itu, Hazairin kemudian mencoba untuk mencari kebenaran hakiki-yang mungkin paling dekat dengan keinginan al-Qur'an dari ayat-ayat kewarisan, berdasarkan keyakinan bahwa Tuhan tentu hanya menginginkan adanya satu kebenaran saja terhadap setiap kemauan-Nya. Suatu kebenaran yang tidak akan diperselisihkan lagi tingkat akurasinya, karena sudah final. (Hazairin, 1976, 18) Usaha ini dimulai dengan menghimpun semua ayat dan hadits yang berhubungan dengan kewarisan, lalu menafsirkannya sebagai satu kesatuan yang saling menerangkan. Usaha ini didukung sepenuhnya oleh hasil temuan ilmu antropologi sebagai kerangka acu (frame of reference) untuk membantu menjelaskan pengertian dan konsep-konsepnya.

Dalam hal ini, Hazairin mengusulkan perlunya memanfaatkan hasil-hasil keilmuan kontemporer (khususnya antropologi) dalam menetapkan hukum-hukum fiqh (kewarisan). Hal ini dimaksudkan untuk menciptakan sistem hukum yang lebih padu dan menyeluruh. Dalam pandangannya, kelahiran dan perkembangan ilmu antropologi telah membuka peluang bagi setiap orang untuk melihat ayat-ayat kewarisan dalam kerangka yang lebih luas, yaitu sistem kekeluargaan dalam berbagai masyarakat dunia. Al-Qur'an yang bersifat universal dan shalib li kulli zaman wa makan, harusnya tidak dipahami dan diacu sebagai kaidah mati, dalam arti semua ketentuan hukum dalam al-Qur'an harus diterapkan 
dalam kehidupan praksis dengan tanpa melihat kondisi dan situasi masyarakat sekitar, dengan konsekuensi melakukan tambal sulam terhadap hal-hal yang dirasa bertentangan. Kondisi seperti ini semakin parah dengan adanya pihak yang coba memahami ayat-ayat (kewarisan), hanya dalam kerangka adat masyarakat Arab masa nabi per se, sehingga membawa implikasi pada terjadinya benturan antara satu masyarakat dengan masyarakat lainnya yang memiliki sistem dan bentuk kekeluargaan yang berbeda.

Penggunaan ilmu kontemporer (antropologi) sebagai kerangka acu tambahan dalam pola kerja pemikiran hukum Islam Hazairin ternyata telah membuat posisi ushul fiqh menjadi 'terpinggirkan'. Pendekatan yang tidak lazim ini menjadi problem tersendiri dan bisa dikatakan sebagai faktor penyebab mengapa pemikiran Hazairin ini kurang mendapatkan respons positif dan proporsional dari masyarakat luas. Bahkan pemikiran ini banyak mendapat tantangan dari kalangan ulama NU. (K.N. Sofyan Hasan dan Warkum Sumitro, 1994: 104)

Hazairin sendiri memahami dan mengakui keberadaan fiqh dan juga ushul fiqh sebagai produk dan metode pemikiran hukum yang mengatur hubungan antara manusia dengan Tuhannya, manusia dengan sesama manusia, manusia dengan makhluk hidup selainnya, dan antara manusia dengan segala macam benda. Sebagai hasil pemikiran, fiqh bisa melahirkan norma (hukum). Sedangkan ushul fiqh sebagai 'pokok' dari fiqh adalah spare part yang mampu menggerakkan pemikiran ijtihad dengan landasan al-Qur'an, sunnah, ijma', dan qijas. (Hazairin, 1982: 62) Dimensi pemikiran hukum yang selama ini tertuang dalam kitab fiqh, dengan demikian, senantiasa akan menerima perubahan-perubahan dari segi materi maupun metode pengembangannya.

Usaha untuk merekonstruksi format fiqh baru, menurut pandangan Hazairin, dapat dimulai dengan tafsir otentik atas al-Qur'an. Dalam analisis dan hasil temuan dari studi tentang pemikiran waris Hazairin yang dilakukan oleh Al-Yasa' Abu Bakar, dapat ditarik kesimpulan bahwa karakter sumber-sumber hukum Islam, yakni sunnah, ijma', dan qiyas memungkinkan untuk digugat hasil ketetapan ijtihadnya. (Hazairin, 1982: 25-31)

Oleh karena itu, Hazairin coba menawarkan pola penafsiran baru atas al-Qur'an, yaitu dengan menginkorporasikan keilmuan modern, dalam hal ini antropologi, ke dalam proses penafsiran, serta memberikan prasangka sebelum memulai pekerjaannya. Pola penafsiran baru ini tentu mempunyai konsekuensi tersendiri terkait dengan pola-pola penafsiran mainstrem yang selama ini berkembang. Penalaran Hazairin ini mengkonsekuensikan adanya penyelarasan ayat-ayat al-Qur'an (tentang 
waris) dengan hadits nabi, dan pencarian arti 'kata kunci dalam al-Qur'an, dengan al-Qur'an sendiri. Yang pertama didasarkan pada pemikiran

dia sebelumnya, yang mengatakan bahwa hadits akan tertolak apabila bertentangan dengan hasil penafsiran ayat dengan ayat. Sedangkan yang kedua, dengan memakai kerangka di atas, dimaksudkan untuk mencari perbandingan, sehingga dari sini dapat diambil kesimpulan yang lebih tepat. Langkah yang terakhir ini dilakukan untuk menunjukkan arti penting aplikasi pendekatan antropologi, yang diyakini akan memberikan pemahaman yang tepat dalam proses penafsiran. Dalam hal ini, Hazairin tidak mengandalkan buku kamus, menghindari kajian semantik dan studi derivasi kata Arab, bahkan dia banyak mengkritik ulama Sunni karena sangat terpengaruh dengan tradisi Arab dalam memahami teks. Dalam amatannya, beberapa istilah di dalam AI-Qur'an yang menurut sebagian ulama memiliki arti bias, ternyata mempunyai arti khusus menurut $\mathrm{Al}$ Qur'an sendiri.

Demikianlah gambaran umum dari metode wacana Fiqh Madzhab Nasional yang coba didemonstrasikan oleh Hazairin melalui tulisantulisannya sejak tahun 1950 hingga 1958. Dari sini dapatlah disimpulkan bahwa Hazairin memakai metode induktif dan deduktif secara serentak di dalam menginterpretasikan teks al-Qur'an dan hadits. Dengan model seperti itu, ia memandang qiyas lebih sebagai kegiatan penalaran daripada sebagai dalil atau sumber itu sendiri. Sebagai pengejawantahan dan penggambaran dari wacana pemikirannya ini, bagaimana potret ijtihad hukum yang ditawarkan oleh Hazairin?

Sebagaimana telah disinggung di muka, ijtihad hukum yang dilakukan Hazairin adalah dalam medan hukum kewarisan. Menurutnya, konsep hukum kewarisan Islam yang selama ini berjalan dengan menganut sistem patrilineal (menarik garis keturunan hanya dari arah laki-laki saja). Itu sangat dipengaruhi oleh konstruksi budaya Timur Tengah (Arab) yang juga demikian. Hukum kewarisan dalam al-Qur'an, bagi Hazairin, esensinya menganut sistem bilateral, yakni menarik harta dari pihak ayah dan ibu.

Pemikiran ini muncul setelah ia melakukan penelitian atas ayat-ayat al-Qur'an tentang waris, dan melakukan hipotesis (dugaan) bahwa bukan masyarakat yang ber clan atau patrilineal yang dikehendaki al-Qur'an, melainkan yang dikehendaki adalah masyarakat bilateral. Hipotesis ini didasarkan dan dilatarbelakangi oleh fenomena perkawinan sahabat Ali dan puteri Nabi, Fatimah az-Zahra, yang dibenarkan oleh al-Qur'an. Dalam pandangan masyarakat ber clan, sebagaimana terjadi di Arab sebelum datangnya Islam, perkawinan seperti ini, yang biasa disebut 
eksogami, jarang sekali dilakukan, dianggap tabu, dan karena itu tidak dapat dibenarkan.

Dengan adanya restu' dari Al-Qur'an yang mewujud dalam pernikahan ini, Hazairin menarik pemahaman bahwa sistem kekeluargaan dalam al-Qur'an adalah sistem bilateral, bukan patrilineal. Pengandaian sistem kekeluargaan seperti ini berimplikasi pada sistem kewarisannya. Harta yang ditinggalkan oleh orang yang masih hidup juga harus diatur menurut hukum kewarisan bilateral. Dalam ranah antropologi, hukum kewarisan itu adalah kelanjutan dari hukum perkawinan, dan hukum perkawinan tidak boleh berbeda dengan hukum kewarisan.

Pemikiran hukum kewarisan bilateral yang ada dalam Al-Qur'an ini telah memunculkan perspektif sekaligus pandangan baru dalam rangkaian detail dan turunan angka pembagian harta warisan. Implikasi lebih jauh yang ditimbulkan oleh gagasan Hazairin ini menjangkau permasalahan-permasalahan sebagai berikut:

a. Istilah 'ashabah berasal dari adat masyarakat Arab, dan karena itu tidak seharusnya dipertahankan;

b. Kedudukan keturunan melalui anak perempuan, dan seterusnya ke bawah, sama kuatnya dengan keturunan melalui anak laki-laki, dan seterusnya ke bawah;

c. Memasukkan ahli waris karena pergantian ke dalam sistem kewarisan Islam, dengan menggunakan surat an-Nisa' ayat 33 sebagai landasannya;

d. Memperkenalkan pengelompokkan baru untuk ahli waris, yaitu drawi al-furudh, dzawi al-qarabah, dan mawali, sebagai ganti dari dzami al-furudh, 'ashabah, dan drawi al-arbam

e. Ke dalam pengertian kalalah (mati punah) diikutsertakan orang yang hanya mati punah ke bawah (tidak meninggalkan keturunan). Hal ini berbeda dengan fiqh Sunni, yang mengartikan kalalah sebagai orang yang mati tidak meninggalkan keturunan laki-laki dan ayah. Kesimpulan di atas merupakan pendapat dari berbagai buku yang ditulis Hazairin di antaranya adalah Hukum Kewarisan Bilateral menurut Al-Qur'ân dan hadits, Hendak kemana hukum Islam; hukum Kekeluargaan Nasional. Lihat uraiannya pada (Al-Yasa Abu Bakar, tt: 4-5)

Pandangan-pandangan di atas mengandaikan bahwa masingmasing cucu akan mengambil hak ayah dan ibunya yang telah meninggal. Dalam kasus pertama, harta warisan setelah dikeluarkan untuk dzawi alfurudh, kemudian dibagi menjadi empat bagian: satu bagian untuk anak perempuan, satu bagian untuk cucu laki-laki sebagai pengganti dari ibunya, dan dua bagian untuk cucu perempuan sebagai pengganti dari ayahnya. 
Dalam kasus kedua, dengan proses yang sama, cucu melalui anak laki-laki memperoleh $2 / 3$, cucu melalui anak perempuan mendapat $1 / 5$, dan anakanak perempuan kandung masing-masing mendapat $1 / 5$ bagian. (Al-Yasa Abu Bakar, tt: 4-5)

Dalam bingkai pemikiran Hazairin, pandangan-pandangan di atas merupakan hal baru yang muncul sebagai hasil renungan dan pemikiran atas masyarakat Indonesia. Temuan-temuan demikian niscaya hadir, seiring lahirnya intensitas keilmuan pendukung, yaitu antropologi, yang dapat dijadikan jangkar untuk menjangkau penelitian bentuk-bentuk kemasyarakatan dan hubungannya dengan sistem kewarisan dengan cukup kohesif. Dari titik inilah kemudian dilakukan upaya penafsiran ulang terhadap doktrin hukum kewarisan, agar lebih selaras dengan kemajuan ilmu dan keadaan masyarakat di Indonesia. Dengan ijtihad model baru ini, akan ditemukan format hukum figh yang lebih "membumi" bagi masyarakat muslim di Indonesia, sehingga tidak ada istilah helah (biyal) hukum lagi dalam dataran praktis.

\section{Reaktualisasi Ajaran Islam Munawir Sjadzali}

Seiring dengan tumbuhnya kesadaran dan semangat untuk kembali pada agama di kalangan masyarakat Indonesia, terdapat satu fenomena yang cukup memprihatinkan, yakni masih maraknya sikap mendua yang dipraktikkan umat Islam. Hal ini setidaknya terlihat pada sikap dan cara yang mereka tempuh dalam menyelesaikan persoalan keagamaan, khususnya menyangkut perbankan dan kewarisan. Di satu sisi, umat Islam menganggap bahwa bunga atau interest dalam bank adalah riba, namun di sisi lain, tanpa merasa "terganggu" mereka hidup dari bunga deposito dan juga dengan santainya memakai jasa perbankan lainnya. Begitu juga menyangkut kewarisan, di satu sisi masyarakat muslim Indonesia masih menganggap "relevan" segala ketentuan hukum tekstual fara'idh yang terdapat dalam al-Qur'an, namun di sisi lain, mereka justru meminta dan menjalankan fatwa baru yang dianggap "lebih adil" dalam hal pembagian waris. Atau jika langkah itu tidak ditempuh, maka mereka akan melakukan tindakan pre-emptive, yakni membagi harta peninggalan (warisan) keluarga dengan model hibah sebelum orang tua (pewaris) meninggal. (Munawir Sjadzali, dalam Iqbal Abdur Rauf Saimia (ed.), 1988: 2). (Munawwir Syadzali, :1995: 87),

Secara formal, pelaksanaan ajaran agama dengan model demikian memang tidak bisa dikatakan menyimpang atau bertentangan dengan ketentuan al-Qur'an. Namun, secara etik dan moral, tindakan memilah dan memilih ajaran agama ini bisa masuk kategori bîlah atau main-main dengan agama, yang tentunya sangat berbahaya. Secara eklektis, masyarakat akan 
terbiasa mengambil dan menjalankan sisi ajaran agama yang dianggap save dan lebih menguntungkan, dan sebaliknya, meninggalkan dimensi ajaran agama yang dianggap kurang baik, merugikan, dan tidak relevan. Celakanya, semuanya dijalankan serba permisif, tanpa pertimbangan nalar dan etika agama, dan lebih terasa sebagai dorongan hawa nafsu dunia saja. Kenyataan sosial ini menunjukkan bahwa ada yang tidak benar (something wrong) dari cara memahami dan sikap keberagamaan masyarakat Islam yang secara simultan selama ini terus berjalan.

Gagasan reaktualisasi ajaran dalam hukum Islam, yang pertama kali ditawarkan oleh Munawir Sjadzali Mengenai biografi, pendidikan; karya ilmiah serta karir Munawir Sjadzali dapat di lihat pada (Panitia Penulisan Buku 70 tahun Prof. Dr. Munawir Sjadzali, MA., tt: 1-115); (Masnun, 2002: 73-82 ) pada 1985, secara faktual berangkat dari berbagai problem empiris di atas. Di samping realitas empiris seperti dikemukakan di atas, reaktualisasi ajaran Islam yang ditawarkan oleh Munawir juga berangkat dari pengalaman pribadinya, yakni ketika ia menanyakan satu permasalahan tentang agaimana pembagian waris secara adil kepada anakanaknya kepada seorang ulama yang dikatakan sebagai orang yang sangat dipercaya integritas dan penguasaannya akan ilmu agama. Permasalahan yang dihadapi Munawir ini sebenarnya seputar ketidakpuasannya atas konsep waris Islam yang ada, terutama tentang konsep 1-2 bagi ahli waris laki-laki dan perempuan. Menurutnya jika dilihat dari sisi keadilan, maka tentu sangat tidak adil apabila anak laki-lakinya yang telah disekolahkan lebih tinggi dan memakan biaya yang cukup banyak akan tetap menerima pembagian harta warisan dua kali lebih besar dari saudara perempuannnya yang tidak sekolah tinggi. Atas jawaban ulama yang menyarankan untuk pembagian melalui hibah guna menghindari rasa ketidakadilan, ternyata Munawir tetap saja merasa tidak puas dengan jawaban itu. Lihat (Munawir Sjadzali, 1988)

Sebagaimana berulang kali disampaikan dalam berbagai kesempatan, baik melalui ceramah maupun tulisan, Munawir menganggap bahwa kaum muslimin sering kali bersikap ambivalen dalam beragama. Di satu sisi, mereka sebenarnya kurang menyukai doktrin lama sekalipun tidak berani memodifikasi atau meninggalkannya. Namun di sisi lain, secara sembunyisembunyi mereka mencoba mencari celah aman bagi persoalan keagamaan yang dihadapinya, dengan sedikit memaksakan kehendak suatu aturan hukum yang seharusnya dipakai dalam konteks permasalahan lain.

Dalam pandangan Munawir, tanpa disadari, proses reaktualisasi telah menjadi gerak niscaya dan alami dalam kehidupan kaum muslimin. Lihat paparan Munawir mengenai data-data sejarah penafsiran ayat alQur'ân dan pandangan-pandangan ulama yang dianggapnya sebagai 
penanda dan pertanda bagi sejarah dan eksistensi reaktualisasi ajaran agama pada (Munawir Sjadzali, 1988 :6-11).

Susunan yang berkelindan antara nilai-nilai normatif dan upaya penafsiran ulang atas ajaran agama, akan tetap menjadi kebutuhan nyata. Yaitu selama kaum muslimin tetap tertarik untuk tidak melangkahi ketentuan sumber nash (teks agama), tetapi juga tidak bersedia menarik dan menghindarkan diri dari pola kehidupan yang senantiasa berubah. Dengan kata lain, konfigurasi ini merupakan upaya menjaga otentisitas ajaran agama sekaligus kontinuitas tradisi di tengah gerak perubahan. Itu bertujuan agar wajah dan tampilan agama dalam masyarakat tidak rigid, kaku, dan angker, sekaligus juga tidak ijdiwaz, (sak karepe dewe, mengikuti keinginan tanpa batas), akan tetapi sebuah pola yang mencerminkan keduanya. Dalam jangka panjang, sikap ini akan mematangkan fungsi hukum Islam, bukan sekadar kerangka hidup normatif yang terkonstruksi sebagai hukum formal, melainkan sudah berubah menjadi etika yang preferensi-preferensinya ditentukan oleh masyarakat sendiri. Hipokritas yang pada dasarnya merupakan kemunafikan dengan segala proses penggelapan ajaran, akan redup di bawah nalar reaktualisasi. Hakikat usaha ini adalah upaya penafsiran ulang dari seseorang ke orang lain di kalangan kaum muslimin, dengan tanpa mengubah pandangan formal yang dominan di kalangan masyarakat muslim.

Terjadinya proses reaktualisasi ajaran Islam berikut segala konsekuensi yang mengiringinya, dalam catatan Munawir, lebih menunjukkan vitalitas nilai-nilai normatif Islam daripada sekadar upaya inkorporasi unsur asing ke dalam agama, atau usaha mengganti ketentuanketentuan hukum agama dengan unsur asing. Memang sulit untuk menelisik garis pisah antara keduanya, namun usaha meretas jalan perubahan, walaupun memungkinkan, jelas lebih sulit. Kesadaran yang bisa memudarkan kesulitan adalah pelajaran sejarah, bahwa rintisan perumusan ketentuan yang telah ada merupakan proses dinamisasi hukum agama. Pada ranah demikian ini, hukum agama berkembang menjadi hukum Islam, sebuah sistem hukum yang melayani kehidupan manusia dan mengarahkannya dalam sebuah prosos yang tidak pernah berhenti. Bandingkan dengan (Abdurrahman Wahid, 1997: 15). Menurut Munawir, esensi reaktualisasi adalah kontekstualisasi ajaran Islam itu sendiri. Untuk mempertahankan ajaran Islam yang berkaitan dengan persoalan kemasyarakatan dan mu'amalah, dengan dunia yang terus bergerak maju dan berubah ini, model pemahaman yang hanya mendasarkan pada pemahaman secara harfiyah atau tekstual ayat-ayat al-Qur'an dan hadits harus segera diakhiri. Sebaliknya, harus dilempangkan sebuah jalan bagi pilihan pendekatan dan metode baru, yang dapat digunakan dalam proses 
kontekstualisasi atau bahkan situasionalisasi ajaran, satu usaha yang tetap memahik pada esensi dari petunjuk Ilahi dan tuntutan nabi, serta didasari keyakinan bahwa Islam itu merupakan suatu agama yang memiliki kelenturan. (Munawir Sjadzali, tt : 58 dan 75). Dengan demikian, usaha menampung kebinekaan, yang merupakan fitrah dari kehidupan umat manusia, ke dalam pelaksanaan dan penjabaran ajaran agama tidak bisa dikatakan melanggar kebenaran dan tata nilai yang bersifat abadi dan universal dari ajaran Islam.

Sebagai upaya pencarian makna dan horizon baru dari satu dimensi ajaran agama yang kurang populer di masyarakat, kehadiran ide reaktualisasi ajaran Islam sering kali memandang polarisasi dan kesalahpahaman. Oleh karena itu, Munawir coba mencari justifikasi teologis-historis. Dalam hal ini ia belajar dari pola beragama dan berhukum yang dikemukakan dan dijalankan oleh Mu'adz Ibn Jabbal, yang dibenarkan oleh nabi dengan tertib hirarki sumber al-Qur'an, sunnah, dan baru kemudian ijtihad. Hal seperti itulah yang juga dianut oleh para sahahat, baik ketika nabi masih hidup ataupun sesudah meninggal, dan kemudian diikuti oleh umat Islam dari generasi-generasi sesudah sahabat. (Munawir Sjadzali, tt : 33-34) Usaha sistematis dan pola berhukum yang dilakukan oleh imam madzhab empat, pada hakikatnya juga merupakan pengejawantahan (identifikasi diri) dari model ijtihad Mu'adz. Sampai titik ini, posisi hirarki yudisial dengan konfirmasi al-Qur'an, sunnah, ijtihad, tetap belum tergoyahkan.

Menurut Munawir, Umar bin Khaththab adalah orang pertama yang melakukan 'deviasi' tekstual dengan cara mengambil kebijaksanaan, keputusan, dan memberikan fatwa hukum yang secara implisit (dan juga eksplisit) tidak sepenuhnya sejalan dengan nash, baik al-Qur'an maupun hadits. Munawir mendata sejumlah kasus penyimpangan yang terjadi pada masa itu, yakni: tentang ghanimah (harta rampasan perang), pembagian zakat untuk mu'allaf, perceraian, penjualan umm al-walad, hukuman bagi pencuri dan pezina, dan ta' $2 \hat{r}$. (Munawir Sjadzali, tt : 38-42) Madzhab Umar ini-begitulah pemikiran Umar ini akhirnya biasa disebutsebagaimana terlihat dalam catatan sejarah, kemudian ditindaklanjuti oleh 'Umar ibn Abd al-Aziz, Abu Yusuf al-Hanafi, 'Izzuddin ibn Abd Salam, asy-Syafi'i, Ath-Tufi, al-Hanbali, dan Muhammad Abduh. (Munawir Sjadzali, tt : 38-42) Dengan cara seperti itu, Munawir ingin mengingatkan kepada para pengkritik gagasannya bahwa upaya reaktualisasi bukanlah gagasan baru, yang tidak memiliki akar kesejarahan yang jelas.

Bisa dikatakan bahwa arti penting agenda reaktualisasi hukum Islam Munawir ini terletak di balik retorika masalah kewarisan yang sebagaimana telah disinggung di muka menjadi titik berangkat dan isu 
sentralnya. Sebagaimana terlihat, dalam hal ini Munawir mencoba belajar dari keberanian Umar Ibn al-Khattab ketika berijtihad dan menerapkan hukum. Langkah dan keberanian Umar inilah yang dijadikan model, ukuran, dan pedoman dalam upaya mengedepankan rub at-tasyrî" atau jiwa syari'at Islam daripada formalisme teks AI-Qur'an dan hadits. Di samping masalah kewarisan, Munawir juga menyinggung sejumlah kasus "bermasalah" lain, yaitu kedudukan wanita, bunga bank, dan kedudukan warga nonmuslim,45 yang dianggapnya perlu dicarikan solusi alternatif agar Islam benar-benar bisa wenjadi agama yang rahmatan lil 'alamin.

Sebagai titik masuk, dan untuk mengingatkan arti pentingnya sebuah tafsir dan strategi baru (reaktualisasi) dalam upaya memahami nash agama, pembahasan masalah kewarisan sendiri terlihat sangat jitu dan tepat sasaran. Masalah ini, selain empiris riil, ia juga menjadi salah satu agenda penting pembahasan materi hukum Islam dari proyek pembangunan hukum nasional Orde baru, yang ketika itu memang bertekad membenahi semua segi penyelenggaraan hukum Islam. Proyek yang akhirnya menghasilkan buku Kompilasi Hukum Islam (KHl) ini, awalnya dimaksudkan untuk menghadirkan semacam buku pegangan bagi para hakim agama agar mampu memberikan kepastian hukum kepada pencari keadilan. (Munawir Sjadzali, 1985: 5-6) Dari sini, maka bisa dikatakan bahwa materi kewarisan yang terdapat dalam buku kedua kompilasi hukum Islam (KHI) sedikit-banyak juga merefleksikan teologi pemikiran reaktualisasi hukum Islam yang digagas oleh Munawir Sjadzali, meskipun konsep pembagian waris yang digagasnya (satu banding satu) belum bisa masuk ke dalam KHI.

Munculnya pemikiran reaktualisasi hukum Islam Munawir sebenarnya berangkat dari beberapa pandangan dasar, yakni: pertama, bahwa pintu ijtihad selalu terbuka; kedua, di dalam aI-Qur'an dan hadits terdapat naskh; ketiga, hukum Islam bersifat dinamis dan elastis; keempat, kemaslahatan dan keadilan merupakan tujuan syari'at; dan kelima, keadilan adalah dasar kemaslahatan. (Munawir Sjadzali, tt: 53) Dengan mengacu pada pandangan-pandangan ini maka terlihat bahwa metode penafsiran dan penemuan hukum yang selama ini telah berjalan (konvensional) terasa anakronistik, sehingga satu tatanan metode baru yang dapat digunakan untuk menyelesaikan berbagai masalah aktual menjadi sangat mendesak dan mutlak diperlukan. Dalam hal ini Munawir memandang dan menawarkan perlunya rekonstruksi konsep qath'i- zhanni, dan dipakainya hermeneutika dalam segala gerak penafsiran teks, baik al- Qur'an maupun hadits.

Sebagaimana sudah sering diungkap dalam berbagai buku epistemologi hukum Islam, bahwa konsep qath'i-zhanni merupakan teori 
pokok yang dikembangkan oleh para ulama untuk memahami al-Qur'an dan hadits dalam perspektif penalaran fiqh. (Al-Yasa Abu Bakar, dalam Eddi Rusdiana Arif, 1991: 173.) Sebagai istilah, konsep qatb'i-z̧ hanni tidak dapat ditemukan di dalam al-Qur'an dan hadits. Kedua istilah ini menjadi 'aman' dari gugatan karena keserupaannya yang kuat dengan kategori mubkam-mutasyabih yang secara eksplisit telah diintrodusir al-Qur'an. Keduanya sama-sama berangkat dari sudut semantik (bahasa), bukan dari sudut ide (substansi). Bedanya, qath'i-zhanni digunakan untuk memahami ayat-ayat hukum, sedangkan mubkam-mutasyabib digunakan untuk memahami ayat-ayat non hukum. (Masdar F. Mas'udi, dalam Iqbal Abdurrauf Saimina : 182) Sayangnya, dalam hal perlunya rekonstruksi konsep ini, Munawir tidak memberi penjelasan lebih lanjut mengenai alasan-alasan yang mendorongnya untuk melakukan hal itu, kecuali hanya menunjukkan beberapa bukti sejarah, berupa penyimpangan dalam berhukum dari ketentuan ayat yang masuk kategori qath'i (pasti) yang dilakukan oleh para sahabat nabi. Munawir seakan telah merasa cukup dalam memberikan penjelasan dengan sekadar membeber bukti ini, yang secara eksplisit menunjukkan bahwa satu ketentuan hukum yang qath'i sekalipun sebenarnya juga mempunyai peluang untuk ditafsirkan secara berbeda.

Munawir memandang fiqh, kaidah-kaidah fiqh, dan ushul fiqh, tidak lebih dari sekadar produk pemikiran per se, yang tidak terbebas dari ruang dan waktu. Sebagai pelapisan, beberapa kaidah fiqh dan ushul fiqh yang bersifat umum, terasa masih mempunyai relevansi hingga sekarang. Manhaj atau metode berpikir dalam kaidah fiqh dan ushul fiqh inilah yang dalam amatan Munawir, hendaknya menjadi bagian dari sejarah pemikiran hukum lslam klasik yang harus dikedepankan sebagai acuan dalam proyek reaktualisasi hukum Islam. Dengan demikian, reaktualisasi hukum Islam Munawir sebenarnya juga masih mengikatkan diri dengan madzhab hukum yang ada.

Munawir bisa menerima ketentuan al-Qur'an yang mengatakan bahwa lakilaki mendapat bagian dua kali lebih besar dari perempuan dalam pembagian harta waris, jika memang ketentuan ini membawa implikasi tanggungjawab penuh (untuk membayar mas kawin atau mahar, nafkah, dan perumahan) dari pihak laki-laki sebagai suami. Persoalannya, bukankah tradisi di Indonesia tidak demikian? Dalam amatan Munawir, tradisi mahar di Indonesia sekarang ini tinggal formalitas semata. Selain itu, istri dan suami sama-sama mencari nafkah untuk memenuhi kebutuhan hidup keluarganya. Dengan demikian, maka hubungan antara suami dan istri tidak lagi merupakan hubungan antara yang memberi dan yang menerima, akan tetapi hubungan dua anak manusia yang sepakat 
untuk hidup bersama dan membina keluarga atas dasar gotong royong, masing-masing bekerja mencari nafkah untuk tegaknya rumah tangga. Atas dasar pengamatan empiris ini, Munawir berpendapat bahwa pembagian laki-laki dua kali lebih besar dari perempuan tidak lagi relevan. (Masdar F. Mas'udi, dalam Iqbal Abdurrauf Saimina : 62)

Menurut Munawir, kalau penafsiran al-Qur'an dilakukan secara menyeluruh, dalam arti bahwa penafsiran yang dilakukan senantiasa mengaitkan antara ayat yang satu dengan ayat yang Iain, kiranya masalah di atas dapat diatasi. Ayat 176 dari surat an-Nisa' yang secara eksplisit mengatakan bahwa anak laki-laki mendapat bagian dua kali lebih besar dari anak perempuan, apabila dikaitkan dengan surat an-Nahl ayat 90 yang berisi perintah untuk berbuat adil dan kebajikan, maka akan terlahir satu pemahaman bahwa suatu ketentuan hukum itu harus sesuai dengan rasa dan semangat keadilan di tengah masyarakat, di mana hukum itu akan diberlakukan. (Masdar F. Mas'udi, dalam Iqbal Abdurrauf Saimina : 62-63) Dalam konteks inilah secara implisit Munawir mengusulkan pembagian harta waris di Indonesia dengan ketentuan sama (satu banding satu) bagi anak laki-laki dan anak perempuan.

\section{B. Kedudukan Fiqh Dalam Sistem Hukum Indonesia dan hubungan fiqh dengan perundang-undangan Indonesia}

\section{Kedudukan Fiqh Dalam Sistem Hukum Indonesia}

Pada umumnya masyarakat Islam, khususnya masyarakat Islam Indonesia, memandang fiqh identik dengan hukum Islam, dan hukum Islam dipandang identik dengan aturan Tuhan. Sebagai akibatnya, fiqh cenderung dianggap sebagai aturan Tuhan itu sendiri. Dengan cara pandang itu, maka kitab-kitab fiqh dipandang sebagai kumpulan hukum Tuhan, dan karena hukum Tuhan adalah hukum yang paling benar dan tidak bisa dirubah maka kitab-kitab fiqh bukan saja dipandang sebagai produk keagamaan, tapi sebagai buku agama itu sendiri. Akibatnya, selama berabad-abad fiqh menduduki tempat yang amat terpandang sebagai bagian dari agama itu sendiri, dan bukan bagian dari produk pemikiran keagamaan.

Akibat lebih lanjut dari kedudukan fiqh yang diidentikkan dengan agama itu, maka orang yang menguasai fiqh yang biasanya disebut fugaha, juga mempunyai kedudukan tinggi, bukan saja sebagai orang yang memaklumi produk pemikiran keagamaan tapi sebagai penjaga hukum agama itu sendiri. Secara sosiologis kedudukan demikian itu memberi hak-hak istimewa dan peranan tertentu kepada fuqaha pada lapisan sosial tertentu, yang pada gilirannya akan mempengaruhi cara pandang dan cara pikir fuqaha itu sendiri. Ketika seorang faqih dari 
suatu masa menuliskan tintanya menjadi kitab fiqh, maka sebenarnya itu tidak terlepas dari cara pandang dan cara pikirnya yang sebagian atau seluruhuya diwarnai oleh kedudukan sosialnya tadi.

Di sini, sebenarnya terjadi siklus yang menarik diamati: bahwa untuk menjaga dan memeliharanya, fiqh memerlukan penjaga yang disebut faqih atau fuqaha, dan untuk memelihara status diri mereka, maka para fuqaha memerlukan kehidupan fiqh yang tinggi. Kadangkadang fiqh yang dipeliharanya itu adalah produk para pendahulunya, tapi kadang-kadang juga produksinya sendiri. Ironisnya, produk-produk pemikiran fiqh itu dianggap sebagai identik dengan hukum Tuhan itu sendiri, Demikian kesalahpahaman yang terjadi di kalangan sementara orang Islam, tidak terkecuali di Indonesia, dalam memandang fiqh. Kekeliruan ini rasanya perlu diperbarui dan dibetulkan.

\section{Hubungan Fiqh Dengan Perundang-undangan Indonesia}

Sebagaimana kita ketahui dalam Undang-undang No. 1 tahun 1974 menerangkan bahwa tentang perkawinan yang sesuai dengan fiqh Islam di Indonesia adalah sebagaimana yang tercantum dalan pasal - pasal di bawah ini di antaranya adalah :

\section{Pasal 8}

Perkawinan dilarang antara dua orang yang:

a. berhubungan darah dalan garis keturunan lurus ke bawah atau ke atas;

b. berhubungan darah dalam garis keturunan menyamping yaitu antara saudara, antara seorang dengan seorang saudara orang tua dan antara seorang dengan saudara neneknya;

c. berhubungan semenda, yaitu mertua, anak tiri, menantu dan ibu/bapak tiri;

d. berhubungan susuan, anak susuan, saudara dan bibi/paman susuan;

e. berhubungan saudara dengan isteri atau sebagai bibi atau kemenakan dari isteri, dalam hal seorang suami beristeri lebih dari seorang;

f. yang mempunyai hubungan yang oleh agamanya atau praturan lain yang berlaku dilarang kawin.

\section{Pasal 9}

Seorang yang terikat tali perkawinan dengan orang lain tidak dapat kawin lagi, kecuali dalam hal yang tersebut dalam Pasal 3 ayat (2) dan dalam Pasal 4 Undang-undang ini.

\section{Pasal 10}

Apabila suami dan istri yang telah cerai kawin lagi satu dengan yang lain dan bercerai lagi untuk kedua kalinya, maka diantara mereka tidak boleh dilangsungkan perkawinan lagi, sepanjang hukum, masing-masing agama dan kepercayaan itu dari yang bersangkutan tidak menentukan lain. 


\section{Pasal 26}

(1) Perkawinan yang dilangsungkan dimuka pegawai pencatat perkawinan yang tidak berwenang, wali nikah yang tidak sah atau yang dilangsungkan tanpa dihadiri oleh 2 (dua) orang saksi dapat dimintakan pembatalannya oleh keluarga dalam garis keturunan lurus ke atas dari suami atau isteri, jaksa dan suami atau isteri.

\section{Pasal 42}

Anak yang sah adalah anak yang dilahirkan dalam atau sebagai akibat perkawinan yang sah.

\section{KEBIJAKAN BERDASAR UNDANG UNDANG NOMOR 11 TAHUN 2006 (Ruang Lingkup Aceh)}

Di antara hasil kesepakatan MoU Helsinki yang terjadi pada 15 Agustus 2005, adalah keharusan menulis sebuah rancangan undangundang tentang Aceh yang akan mengakomodir semua isi kesepakatan dan hal-hal lain yang dianggap baik dan perlu untuk Aceh. Rancangan ini disahkan sebagai Undang-Undang nomor 11 Tahun 2006 tentang Pemerintahan Aceh. Dalam undang-undang ini istilah syari'at Islam dan pelaksanaan syari'at Islam disebutkan di banyak tempat, masuk ke dalam berbagai bidang, relatif lebih luas dan lebih menyeluruh dan apa yang sudah ada sebelumnya.

Dalam undang-undang ini (seluruhnya berisi $40 \mathrm{bab}, 273$ pasal) ada tiga bab tentang pelaksanaan Syari'at Islam yang diletakkan secara berurutan yaitu Bab XVII Syari'at Islam dan Pelaksanaannya, Bab XVIII Mahkamah Syar'iyah, Bab XIX Majelis Permusyawaratan Ulama. Berbeda dengan UU 18/01, bab tentang kepolisian dan kejaksaan diletakkan terpisah dengan Mahkamah Syar'iyah, diiringkan dengan Tentera Nasional Indonesia yaitu Bab XXV Tentera Nasional Indonesia, Bab )O(VI Kepolisian dan Bab XXVII Kejaksaan. Perlu juga dinyatakan UU No 11/06 secara tegas mencabut UU 18/01, tetapi tidak mencabut UU 44/99. Dengan demikian aturan tentang keistimewaan Aceh yang ada di sana sepanjang tidak diatur dalam UU baru mi tentu masih tetap berlaku. Pengertian Syari'at Islam misalnya, karena tidak didefinisikan lagi di dalam UU 11/06, maka masih menggunakan definisi yang ada dalam UU 44/99.

Di luar bab bab-bab di atas istilah syari'at Islam masih ada disebut dan digunakan, yang sebagian daripadanya yang dianggap penting penulis kutip sebagai berikut. 


\section{Bab V Urusan Pemerintahan (Pasal 16-19) \\ Pasal 16:}

(2) Urusan wajib lainnya yang menjadi kewenangan Pemerintah Aceh merupakan pelaksanaan keistimewaan Aceh yang antara lain meliputi:

a. Penyelenggaraan kehidupan beragama dalam bentukpelaksanaan syari'at Islam bagi pemeluknya di Aceh dengan tetap men jaga kerukunan hidup antar umat beragama;

b. Penyelenggaraan kehidupan ad at yang bersendikan agama Islam;

c. Penyelenggaraan pendidikan yang berkualitas serta menambah materi muatan lokal sesuai dengan syari'at Islam;

d. Peran ulama dalam penetapan kebijakan Aceh; dan

e. Penyelenggaraan dan pen gelolaan ibadah haji sesuai dengan peraturan perundang-undangan. (Alyasa Abubakar, 2008: Hal 76)

Dalam Pasal 20 (Bab VI Asas serta Bantuk dan Susunan Pen yelenggara Pemerintahan Pasal 20-21) mengenai asas umum penyelenggaraan pemerintahan di Aceh,dicantumkan sebelas buah asas dan yang pertama daripadanya adalah "asas keIslaman. "Begitu juga dalam Pasal 46 (Bab VIII Pemerintah Aceh dan Pemerintah Kabupaten/Kota Pasal 39 - 55) mengenai kewajiban gubernur/wakil gubernur serta bupati/wakil bupati dan walikota/wakil walikota dalam melaksanakaan tugas, dinyatakafl bahwa salah satu kewajibanflYa adalah "menjalankan syari'at agamanya.

\section{Dalam Pasal 99 (Bab XIII Lembaga Adat Pasal 98- 99)}

Tentang pembinaan kehidupan adat juga disebutkan bahwa: "Pembinaan kehidupan adat dan adat istiadat dilakukan sesuai dengan perkembangan keistimewaafl dan kekhususan Aceh yang berlandaskan pada nilai-nilai syari'at Islam dan dilaksanakafl oleh Wali Nanggroe.”

Kembali ke aturan tentang pelaksanaan syari'at Islam, secara relatif rinci ditemukan dalam Bab XVII tentang Syari'at Islam dan Pelaksanaaflflya, Bab XV111 tentang Mahkamah S yar'iyah dan Bab XIX tentang Majelis Permusyawaratan Ulama. Sedang dalam Bab lainnya masih ditemukan pasal-pasal yang berkaitan dengna pelaksanaafl syari'at islam yaitu tentang zakat. Dalam undangundang mi zakat ditetapkan sebagai Pendapatan Ash Daerah (PAD) dan menjadi penguraflg atas pajak penghasilan terhutang. Baitul Mal Aceh dan baitul mal kabupaten/kota ditetapkan sebagai badan resmi pengelola zakat, wakaf dan harta agama. Ada juga pasal tentang tugas dan hubungan kepohisian dan kejaksaan dengan penegakan syari'at Islam serta pasal tentang sanksi syari'at yang 
boleh ada dalam Qanun Aceh, penegakan Qanun Aceh oleh Wilayatul Hisbah serta hak uji materil Qanun Aceh di bidang syari'at Islam yang hanya ada pada Mahkamah Agung. Pasal-pasal tersebut penulis kutipkan secara relatif lengkap sebagai berikut.

\section{Bab XVII \\ Syari'at Islam dan Pelaksanaannya, \\ Yang terdiri dari 3 Pasal Salah satunya : \\ Pasal 125:}

(1) Syari'at Islam yang dilaksanakan di Aceh meliputi aqidah, syari'ah dan akhlak;

(2) Syari'at Islam sebagaimana dimaksud pada ayat (1) meliputi ibadah, ahwal al syakhshiyyah (hukum keluarga), mu'amalah (hukum perdata), jinayah (hukum pidana), qadha' (peradilan)1 tarbiyah ( pendidikan dakwah, syi'ar dan pembelaan Islam;

(3) Ketentuan lebih lanjut mengenai pelaksanaan syari'at Islam sebagaimana dimaksud pada pada ayat (1) diatur dengan wanun aceh (Alyasa Abubakar, 2008: 76)

Dari uraian kutipan di atas terlihat bahwa kebijakan menjadikan pelaksanaan syari'at Islam di Aceh sebagai upaya pembentukan dan penyusunan hukum positif Aceh yang berdasarkan syari'at Islam, sebagai sub sistem dalam sistem hukum nasional menjadi semakin jelas dan kongkrit. Hal ini terlihat dari adanya izin kepada Aceh untuk mempunyai hukum sendiri dibidang ahwal al-syakhsiyyah (perdata kekeluargaan), mu'amalah (perdata keharta-bendaan) dan jinayat (pidana) baik hukum matenil ataupun hukum formil yang didasarkan kepada syari'at Islam dan dituangkan dalam bentuk Qanun Aceh (Pasal 128 dan Pasal 132). Dengan kata lain Aceh diberi izin untuk mempunyai hukum positif sendiri sebagai sub sistem dalam sistem hukum nasional Indonesia.

Untuk melaksanakan syari'at Islam yang akan menjadi hukum positif di Aceh dibentuk sebuah sistem peradilan baru sebagai bagian dan sistem peradilan nasional, yaitu peradilan syari'at Islam dan dilaksanakan oleh Mahkamah Syar'iyah yang hanya ada di Aceh.Tetapi peradilan mi tidak bediri sendiri tetapi diletakkan dalam lingkungan peradilan aama dan berpunca ke Mahkamah Agung. Permohonan kasasi dan peninjauan kembali harus dimintakan kepada (menjadi kewenangan) Mahkamah Agung. Pengangkatan hakim, pembinaan administrasi dan teknik yudisial peradilan, serta pembiayaan dan sebagainya, semuanya berada di bawah Mahkamah Agung. 
Dengan ketentuan ini mungkin timbul pertanyaan apa maksud pembentukan peradilan khusus yang diberi nama peradilan syari'at Islam Islam kalau toh semuanya berpunca ke Mahkamah Agung. Undangundang tidak menjelaskannya secara rinci. Namun dan bahan yang ada seperti diuraikan di atas dapat disimpulkan bahwa maksud peradilan syari'at Islam sebagai sebuah sub sistem dalam sistem peradilan nasional adalah, badan peradilan mi mempunyai hukum materil dan formil sendiri, yaitu yang ditetapkan dengan Qanun Aceh, bukan

\section{SIMPULAN}

Di antara hasil ijtihad Hasbi yang mencerminkan pemikiran Fiqh Indonesia terlihat dalam fatwa hukum jabat tangan antara laki-laki dan perempuan. Di sini ia berbeda pendapat dengan fatwa Majelis Tarjih Muhammadiyah dan Ahmad Hassan dari Persis yang mengharamkan praktik dan perilaku ini. Hasbi menolak mengharamkan praktik jabat tangan antara laki-laki dan perempuan karena beberapa alasan, di antaranya adalah karena hukum haram tersebut dilandaskan pada qiyas. Dalam pandangan Hasbi, mengharamkan sesuatu harus berdasarkan dalil nash yang qath'i, tidak boleh hanya dengan qiyas. Oleh karena tidak ada dalil yang qath' $i$, baik dalam al-Qur'an maupun As-Sunnah, yang mengharamkan praktik jabat tangan antara laki-laki dan perempuan maka praktik seperti itu tidak dilarang agama.

Usaha untuk merekonstruksi format fiqh baru, menurut pandangan Hazairin, dapat dimulai dengan tafsir otentik atas al-Qur'an. Dalam analisis dan hasil temuan dari studi tentang pemikiran waris Hazairin yang dilakukan oleh Al-Yasa Abu Bakar, dapat ditarik kesimpulan bahwa karakter sumber-sumber hukum Islam, yakni sunnah, ijma', dan qiyas memungkinkan untuk digugat hasil ketetapan ijtihadnya.

Munculnya pemikiran reaktualisasi hukum Islam Munawir sebenarnya berangkat dari beberapa pandangan dasar, yakni: pertama, bahwa pintu ijtihad selalu terbuka; kedua, di dalam al-Qur'an dan hadits terdapat naskb; ketiga, hukum Islam bersifat dinamis dan elastis; keempat, kemaslahatan dan keadilan merupakan tujuan syari'at; dan kelima, keadilan adalah dasar kemaslahatan. Dengan mengacu pada pandangan-pandangan ini maka terlihat bahwa metode penafsiran dan penemuan hukum yang selama ini telah berjalan (konvensional) terasa anakronistik, sehingga satu tatanan metode baru yang dapat digunakan untuk menyelesaikan berbagai masalah aktual menjadi sangat mendesak dan mutlak diperlukan. Dalam hal ini Munawir memandang dan menawarkan perlunya rekonstruksi konsep qath' $i$ - zhanni, dan dipakainya hermeneutika dalam segala gerak penafsiran teks, baik al- Qur'an maupun hadits. 


\section{DAFTAR PUSTAKA}

Al-Yasa Abu Bakar, "Beberapa Teori Penalaran Fiqh dan Penerapannya", dalam Eddi Rusdiana Arif, dkk (ed), Hukum Islam di Indonesia, (Bandung: Remaja Rosda Karya, 1991) Desember 2008,

Atho' Mudzhar, Catatan-catatan kuliah Sejarah Sosial Hukum Islam pada Fakultas Pasca Sarjana, IAIN Jakarta, 1990/1991.

Entri Hazairin, Apa dan siapa Orang-orang Indonesia1981-1982, Cet. 1,(Jakarta: Grafity Press, 1981);

H. Kusdar Dinamika Fiqh Di Indonesia (Telaah Historis Lahirnya Fiqh Keindonesiaan)

Hasan Shadily (ed.), Ensiklopedi Indonesia, jilid 1, (Jakarta: khtiar Baru, 1980);

Hasbi ash-Shiddieqy, Beberapa Permasalahan Zakat (Jakarta: Tinta Mas, 1976)

Hasbi ash-Shiddieqy, Falsafah Hukum Islam, (Jakarta: Bulan Bintang, 1975),

Hasbi ash-Shlddieqy, Syariat Islam Menjawab TantaNgan Zaman, Jakarta Bulan Bintang 1966)

Hazairin, Hukum kekeluargaan Nasional, (Jakarta: Tintamas, 1982

Hazairin, Hukum Kewarisan Bilateral menurut Qur'an dan Hadits, (Jakarta: Tintamas, 1982),

K.N. Sofyan Hasan dan Warkum Sumitro, Dasar-dasar Memahami Hukum Islam di Indonesia, (Surabaya, Usaha Nasional, 1994),

Masdar F. Mas'udi, "Memahami Ajaran Suci dengan Pendekatan Transformatif", dalam Iqbal Abdurrauf Saimina (ed)., 
Munawir Sjadzali, Reaktualisasi ajaran Islam, dalam Iqbal Abdur Rauf Saimia (ed.), Polemik Reaktualisasi Ajaran Islam, (Jakarta; Pustaka Panjimas 1988),

Munawwir Syadzali, Prof. Dr. H. MA., Kontekstualisasi Ajaran Islam, (Jakarta: Ikatan Persaudaraan Haji Indonesia (IPHI), 1995),

Retno Lukito, Pergumuan antara Hukum Islam dan Adat di Indonesia, (Jakarta: INIS, 1988)

Sayuti Thalib, Pembaharuan Hukum Islam di Indonesia: in Memoriam Prof. Mr. dr. Hazairin, (Jakarta: UI Press, tt.).

Syamsul Wahidin dan Abdurrahman, Perkembangan Ringkas Hukum Islam di Indonesia, (Jakarta: Akademika Presindo, 1984), 